\title{
Thinking Deren
}

\section{Elinor Cleghorn}

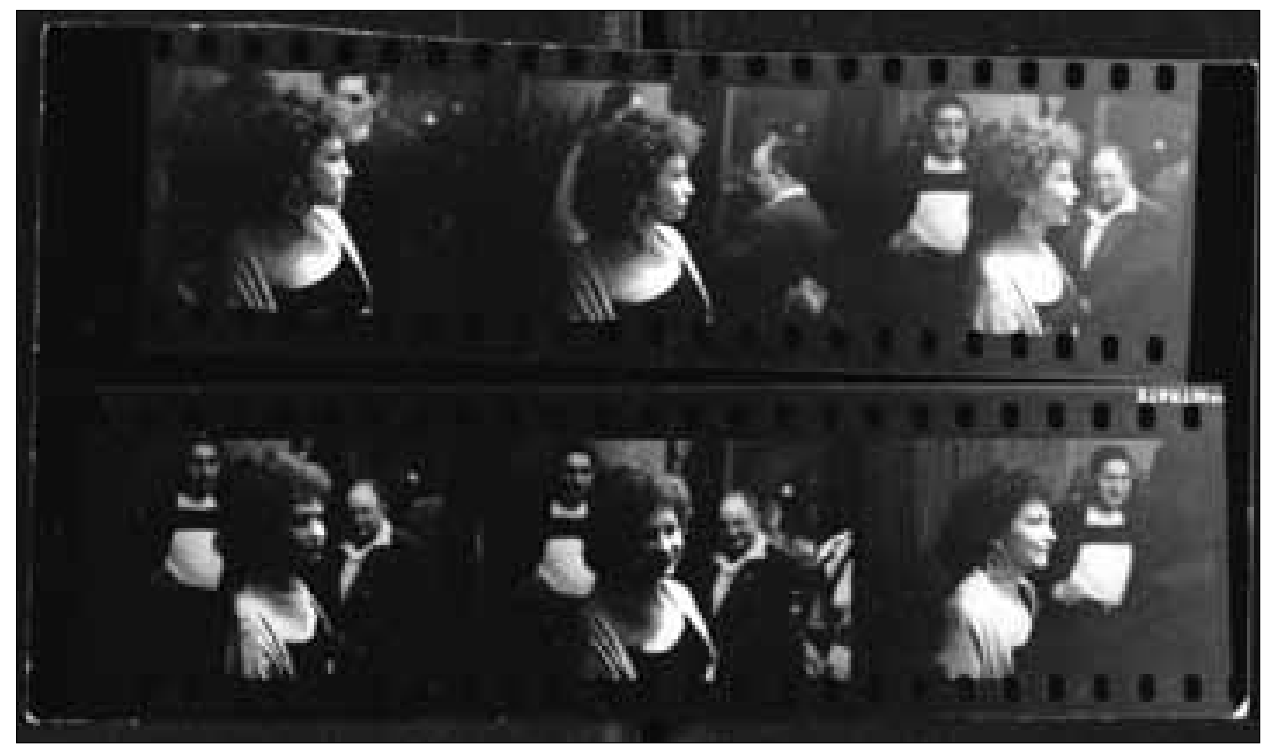

Maya Deren. Film frames. (no date). Reproduced with kind permission of the Maya Deren Collection at the Howard Gotlieb Archival Research Centre, Boston University.

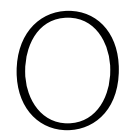

ctober 2011 marks the fiftieth anniversary of the death of Maya Deren: filmmaker, poet, dancer, ethnographer, teacher, visionary. The occasion proffers the opportunity to reconsider Deren's considerable cinematic legacy and to re-view her slight collection of completed works in light of the progression of screen-based practices over the last fifty years. Her work is particularly significant to screendance and choreographic cinema; ripples of her relevance, like rings in water, are present in so many film works seeking to explore the possibilities for moving bodies on screen. In her films, such as A Study in Choreography for Camera (1945) and The Very Eye of Night, which saw its New York release in 1959, the dancing body appears to at once transcend the limitations and the strictures of gravity and of physicality. In Ritual in Transfigured Time, completed in 1946, the movements of guests at a cocktail party become an integrated mechanism through which the capacity of the filmic medium to confer a dance-like quality upon quotidian movement is brought to screen. Meditation on Violence (1948) describes the quality of movement of two qualitatively different schools of Chinese boxing through a solo performance, with which the camera collaborates.

Deren was of course not the first to bring dance to film or to choreographically configure elements and objects into an integrated cinematic complex. A selection of possible films 
that could accompany Deren's A Study in Choreography for Camera in an imagined contextual journey through the pre-1950 history of examples of 'film as art form,' which drew upon the notion of the choreographic as impulse for cinematic expression, might include: Fernand Léger's Ballet Méchanique (1924), René Clair's Entr'acte (1924), Marcel Duchamp's Anémic Cinéma (1926), Oskar Fischinger's Spiritual Constructions (1927), Germaine Dulac's Étude cinégraphique sur une arabesque (1929), Mary Ellen Bute's Tarantella (1940) and Marie Menken's Visual Variations on Noguchi (1945).

The significance of Deren's contribution to the development of film as an art form inexorably exceeds the parameters of her screen legacy. Her films undoubtedly owe much to the accomplishments of her predecessors - even if she resisted bringing this into discussion. She was audaciously singular, however, in her commitment to assuring a breadth of exposure for her own works whilst previous film artists had suffered from limited visibility, their films often screened only once in very specific circles. During the 1950s, Deren toured lectures, conducted workshops, and gave talks to accompany self-organized screenings of her body of films across the US; she participated in symposia and debated the potential for a collaborative exploration of the relation of the medium and other creative disciplines. Her tireless advocacy for the promotion of independent filmic practice, which included the formation and administration of the Independent Film Maker's Association in 1953, and the Creative Film Foundation in 1955, facilitated the bringing together of New York based artists in the exhibition, distribution and discussion of diverse filmmaking endeavors.' Deren's efforts ensured that, for example, the unique possibilities, which the cinematic mechanism opened up for the treatment of dancing bodies, were brought keenly into debate at a particularly discursive juncture in experimental moving-image production. In 1956 she organized and participated in "Dance and Film," a Creative Film Foundation event held as part of a series entitled "Film - A Creative Synthesis" at the Hanya Holm School in New York. The event comprised screenings intended to illustrate discussions concerning the "variety of relationships between film and dance movement."2 Deren's Choreography for Camera appeared alongside Jean Cocteau's narrated documentary on African dances, L'Amitié Noire (1946), Léger's Ballet Méchanique and Disney's animated short Skeleton Dance (1929). A panel discussion featuring Deren and choreographers Jean Erdman, Valerie Bettis and Antony Tudor considered the relative merits of the screened examples of dance on film. In the audio recording of the event, one can listen to Deren defending her silent depiction of dance for camera against Erdman's proposition that she feels the lack of kinaesthetic empathy when movement on the screen proceeds divorced from sound. ${ }^{3}$ Deren had, between 1952 and 1954, collaborated with Tudor on the production of her final completed film, The Very Eye of Night, for which he choreographed dancers from the Metropolitan Opera Ballet School in movement sequences staged specifically for filmic composition. The set of questions posed in the "Dance on Film" event bulletin resonate most profoundly with continued discussions and debates surrounding the emergence and development of screendance, a medium which has, as we know, not yet been invented:

Dance and motion-pictures are both concerned with movement. What is lost when dance is simply recorded on film? What can be gained by creative use of the film medium and the mobile camera? What are the relative roles of choreographer, dancer and film-maker in a creative collaboration between dance and film? ${ }^{4}$ 
Within the scope of this issue of the International Journal on Screendance, which is titled "Scaffolding the Medium," an opportunity arises to consider Deren's legacy through her writings and lectures in which she gave insight into the conceptual frameworks structuring and enabling the production of her restless and beautifully wrought film works. Whilst no spectator intrigued by screendance is a stranger to her aesthetic, and her first film Meshes of the Afternoon, made in 1943, remains one of the most widely screened examples of experimental cinema in educational institutions, the full breadth of her contribution to film theory remains twilit, and is deserving of thorough attention. Deren wrote prolifically: during the mid-1940s she published essays and articles on the conception and construction of her works, on the practice of creative filmmaking, and on the notion of cinema as an art form in a wide range of publications, most notably Dance Magazine, Popular Photography, New Directions and Mademoiselle. As Bruce McPherson notes in his introduction to Essential Deren, the collection of her writings published in 2005, the intense period of production between 1944 and 1948, which bore four films, coincided with a voluminous outpouring of published material. ${ }^{5}$ McPherson notes that a "publishing hiatus" of about ten years followed, but during this time, Deren continued to write, to tour with lectures, and to cleave out a space in which experimental film could be viewed and valorized.

During a recent trip to the Maya Deren Collection in the Howard Gotlieb Archival Research Centre at Boston University, I encountered carbon copies of original documents typewritten by Deren, often accompanied by tantalizing pencil annotations and

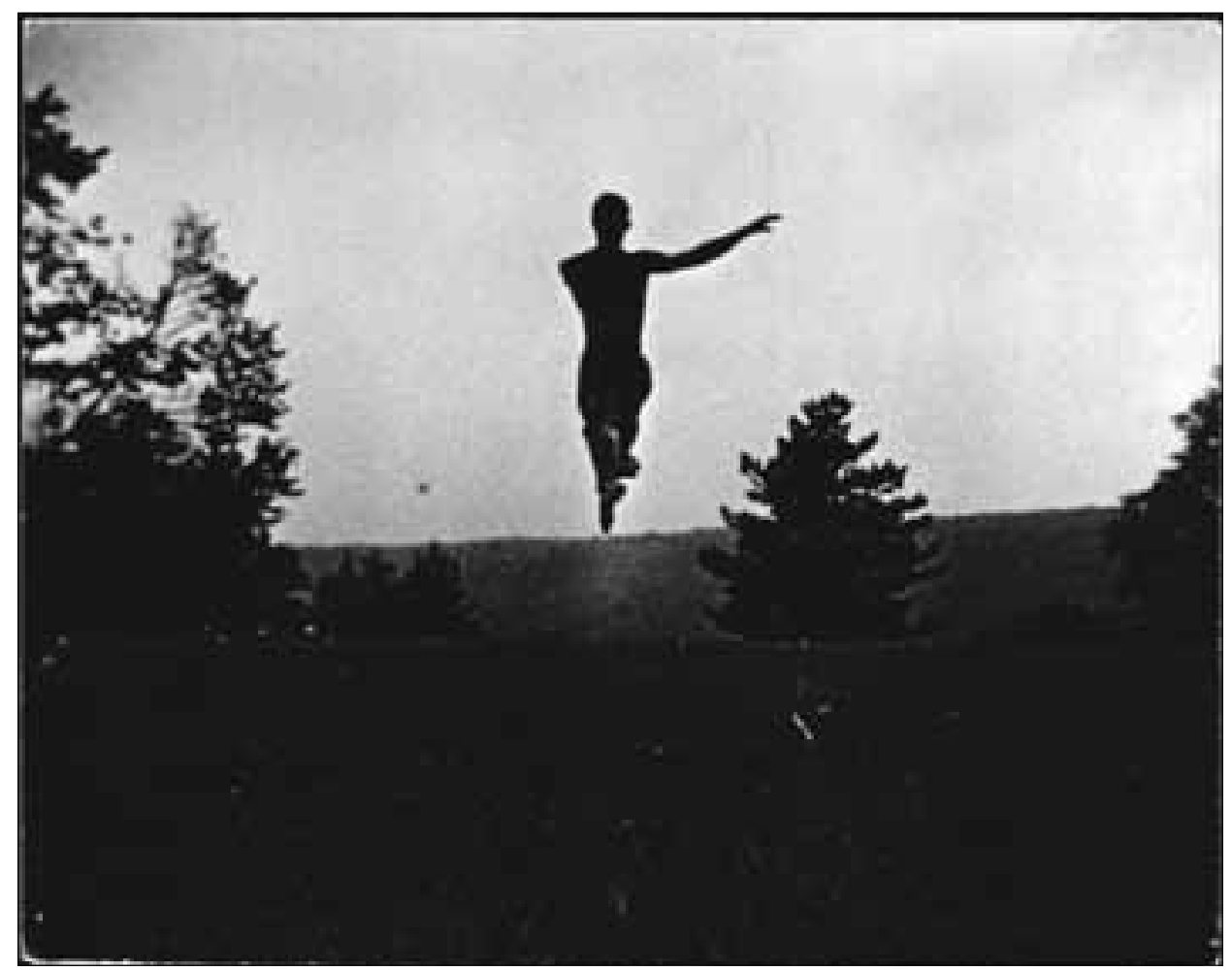

Frank Westbrook, Ritual in Transfigured Time, Maya Deren. Film still. 1945/46. Reproduced with kind permission of the Maya Deren Collection, Howard Gotlieb Archival Research Centre at Boston University. 
notes-to-self. During my search for material that might support my interest in Deren's utilization of her mobile body as the most enabling instrument of her practice, I came across numerous drafted forms of notable articles and thematic statements, the majority of which were included in a memorial edition of Film Culture, which was dedicated to Deren (1956), and which have more recently been made available in Essential Deren. Amongst the manuscripts I was familiar with, I discovered a draft entitled Introduction to the Films, which we have the privilege of including in this edition of The International Journal on Screendance.

The original copy of the draft (1945) includes a note, in parentheses, stating that it was "from a lecture delivered in connection with film showings." by Deren expressing the fundament of the concept of form: the form of the "true work of art," she claimed, was constituted by the capacity of the artist, through their chosen medium, to create an entirely new, experiential reality from elements selected for their purpose of production. In cinematic terms, Deren argued, this imaginative constitution derives from techniques of mechanistic manipulation brought to the elements of natural reality "selected and registered by the lens." In a declamation illustrating the importance of the making body in the conjuring of creative film, she expresses her concern that the mechanical similarity between eye and lens must analogously extend to the body behind the camera, "whose movements are motivated by the meaning which the brain extends to the material which the eye registers." ${ }^{\prime \prime}$ For Deren, the motion picture camera could elicit its most truly creative registers of expression in the hands of the mobile body. As she proclaimed in "Adventures in Creative Film Making," an essay expanding several of the propositions she initiates in her text from 1945, the human body offers a peerless support structure, enabling a range of opportunities for photographing, limited only by the body's capacity for pose or balance. ${ }^{9}$ Through the theoretical optic proposed by this issue of the Journal, we might begin to reconsider Deren's work as scaffolded by the choreographic implications of filmic technology and re-experience the manipulation of the bodies and objects within her frames as intimately extending from the physical engagements of an invested, seeking body. She believed profoundly, as she expresses in her seminal chapbook An Anagram of Ideas on Art, Form and Film (1946), that the potential of a work of art derived from the "skilful exercise and control" of the art instrument through which the maker could fully realize her boundless "imaginative manipulations." ${ }^{10}$

The section of the Journal dedicated to thinking or re-thinking Deren includes my essay, Manus Operandi: Film, Sculpture, Choreography, in which I discuss her unfinished film project of 1943, Witch's Cradle, as a cinematically specific exploration of the relational space between mobile body and sculptural forms. The film, available to view as a series of outtakes, includes scenes shot in the Surrealist gallery of Peggy Guggenheim's "Art of this Century" museum. Deren attempted its making shortly after completing Meshes of the Afternoon with her then-husband, documentary filmmaker Alexander Hammid. It was her first venture in creating a film "quite by herself."11 In viewing the fragments of this project, Deren's animistic characterization of the art objects within the gallery suggest that she sought to transpose into the specificities of filmic form the way in which the selected objects seemed to her to "constitute a strange, magical world."12 Geographically distant scenes are symbolically conjoined by the recurring presence of a strangely enigmatic length of string: whilst the film was never realized and released, it bares evidence of Deren's bourgeoning conceit that film was capable of dynamically conjuring an "emergent whole" (a term she applied 
to the medium from her interest in Gestalt theory) from the composition of unpredictably related "parts."13 Deren was fascinated with Haitian and Balinese forms of ritual expression: her documentation, in 1947, of one Voudoun dance ceremony across 20,000 feet of $16 \mathrm{~mm}$ film remained unedited in her lifetime. ${ }^{14}$ She sought to transpose the integral logic of ritual activity into filmic form, arguing that such activity consisted of the 'fusing' of individual elements into a transcendent unity that strove towards the "accomplishment some critical metamorphosis."15 Deren's interest in Gestalt theory became a mechanism for her cinematic expression of ritual coherence and, along with the verbal logics of poetry, form acted as a conduit for the realization of film as a "controlled manipulation of any or all elements into a form which will transcend or transfigure them."16

Through her thematic statements on A Study in Choreography for Camera of 1945 and Meditation on Violence of 1948 Deren elicited a language with which to talk about choreographic cinema; through her theoretical writings she engendered possibilities for filmic thinking, drawing upon the medium's capacity for ritual, poetic expression and the invention of experiential realities; through her lectures she gave fascinating insights into filmic construction and the visual realization of the imaginary. Her writings and lecture transcripts are full of insights into her relationship with the mechanism of her expression-with her "instrument of action" — and it is my hope that this section of the Journal might invigorate dialogues around the ways in which her intellectual output opens up her films to new, previously unexplored registers of understanding. Deren's films, her theories and her advocacies-which can be approached as an extraordinary contribution to the continuing development of film as art form-were driven by an impulse to explore and discover the social, ritualistic, aesthetic, choreographic, poetic and experiential potentialities of a medium that, for her, was equal to life.

\section{References}

Deren, Maya. "Adventures in Creative Film Making." In McPherson, Essential Deren, 172-73. Originally published in Home Movie Making, 1960.

. An Anagram of Ideas on Art, Form and Film. New York: The Alicat Book Shop Press, 1946. In McPherson, Essential Deren, 54.

."Introduction to the Films." 1945. Maya Deren Collection, Howard Gotlieb Archival Research Centre, Boston University.

."Magic Is New." Mademoiselle. January 1946. In McPherson, Essential Deren, 204.

."Ritual in Transfigured Time." Dance Magazine. December 1946. In McPherson, Essential Deren, 227.

McPherson, Bruce, ed. Essential Deren: Collected Writings on Film by Maya Deren. New York: Documentext, 2005.

Rabinovitz, Lauren. Points of Resistance: Women, Power and Politics in the New York Avant-Garde Cinema, 1943-1971. Urbana: Univ. of Illinois Press, 1991.

\section{Notes}

1. Lauren Rabinovitz, Points of Resistance, 80-83.

2. "Dance and Film at the Hanya Holm School, New York," March 23, 1956, Creative Film Foundation Bulletin, Deren Collection.

3. Wire recording of the Creative Film Foundation event "Dance and Film,"March 23 1956, transcript and audiocassette, Deren Collection.

4. "Dance and Film at the Hanya Holm School, New York," Deren Collection. 
5. Between 1944 and 1948 Deren made At Land (1944), Choreography for Camera (1945), Ritual in Transfigured Time (1945/46) and Meditation on Violence (1948). For Deren's complete filmography, which includes details of her incomplete and unrealized projects, see Bruce McPherson, editor. Essential Deren, 259-60.

6. Deren, "Introduction to the Films."

7. Ibid.

8. Ibid.

9. Reprinted in McPherson, Essential Deren, 172-73.

10. Ibid., 54.

11. Maya Deren,"Magic is New," 204.

12. Ibid.

13. Deren, An Anagram of ldeas on Art, Form and Film, 65.

14. The footage was edited posthumously into the documentary Divine Horseman: The Living Gods of Haiti by Deren's widower Tieji Ito and his wife Cheryl Ito in 1977. Deren's study of the practices and activities of Haitian Voudoun led to the publishing of her text of the same name in 1953.

15. Maya Deren, "Ritual in Transfigured Time," 227.

16. Ibid, 228. 


\section{6 ro}

\section{CREATTVE FILM FOUNDATION 35 Morton atreet, NYC 14 ERtklns 4-0760}

\section{For Immediate Relense}

Plesse Pagt

The Creattve Film Foundation presents

the firat Friday Forum of its series on Film - A Creative Synthesis

March 23, 8:30 PM at the Hanya Holm Bchool, 743 oth kve (40न7 atc)

DANCE AND FILM

\section{VALERTE BETTS * MAYA DEREN • JEAN BRDMAN • ANTONY TUDOR}

Dance and motian-pletures are both concerned with morerent, What is lout

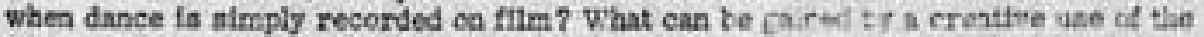

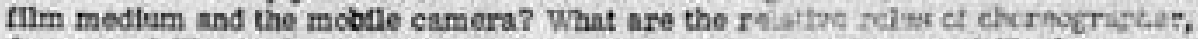
dancer and fllm-maker in a creative collaboration betwotn dasuc is.d fom?

The variety of retationshtpg between film and dance movetnint will be ti-

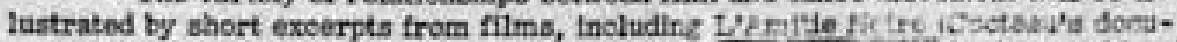

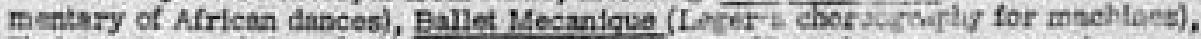

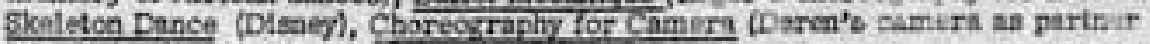
to a dancer) nand others.

There is no admisalons fee. These forims are organised primarlly for Sustalning Members of the Foundation, students in the arta aud perzssa ergaged in $16 \mathrm{~mm}$ film-mnking who are unable to contrlbute as Sustainirs Mer lyts are frvited to attend as gaests and may apply for a gueat adimisatce eant by wrftiag to the Fo and-

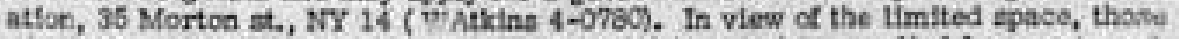
who have made thetr contribution to the Poundation or have applled for guest carda In advnnce will be seated flrat, beforo perstone without advarce reservatlons are scmitted.

The Creatlve Film Foundation is a nen-protit eorporation devotad to the developmeat of motion-plctures as a creative flne art form; It glves graats for experlmental fllm production, confers an Anrual Crentlve Fllm Award, casitucts forams, sponsors exhlbits and other events. These activities are made porafble by the coutributions of Sustaining Members, A denation of \$10,00 or mere qunlifles an Individual for particlpation as Sustaining Member, facludirg the follosing privilegen: attendance at forums, complimeatary tickets to puhtic Poundation eveats, news letters, bocks co fllm at dincounted rates, ete.

\section{THE CURRENT FAMAY FORUM BERTES YIT, AIEO ANCLUDE:}

(5)ces c? forumat will be aninounced)

Aprll 6 - MUSIC AND FIt M: John Cage, John Gruen, Gordon Hiendricks, Norman Lloyd.

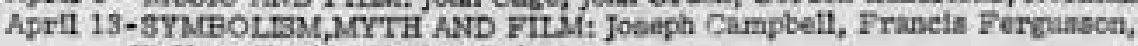
Wallace Fowlie, Parker Tyler.

April 30-POETRY AND FILU (apeakera to bo ameunced.

April 27-THE PLASTTO ARTS AND FTtM: Rudoll Arnholim;Clement Oreenberg, Frederlek KIesler, Meyer Sehapiro, Kurt Sellgmatia.

and …. THEATBR AND FILM; ART AND THE ARTY DN FILM, and others.

HEIP THR DIVET OPMEYT OF FTH AS A FRE ART PORM BY YOUR PARTTCTPATIÓN AND CONTRIBUTHON NOWI

Copy of the original Creative Film Foundation bulletin for "Dance and Film," 1956. Reproduced with kind permission of the Maya Deren Collection, Howard Gottlieb Archival Research Centre at Boston University. 


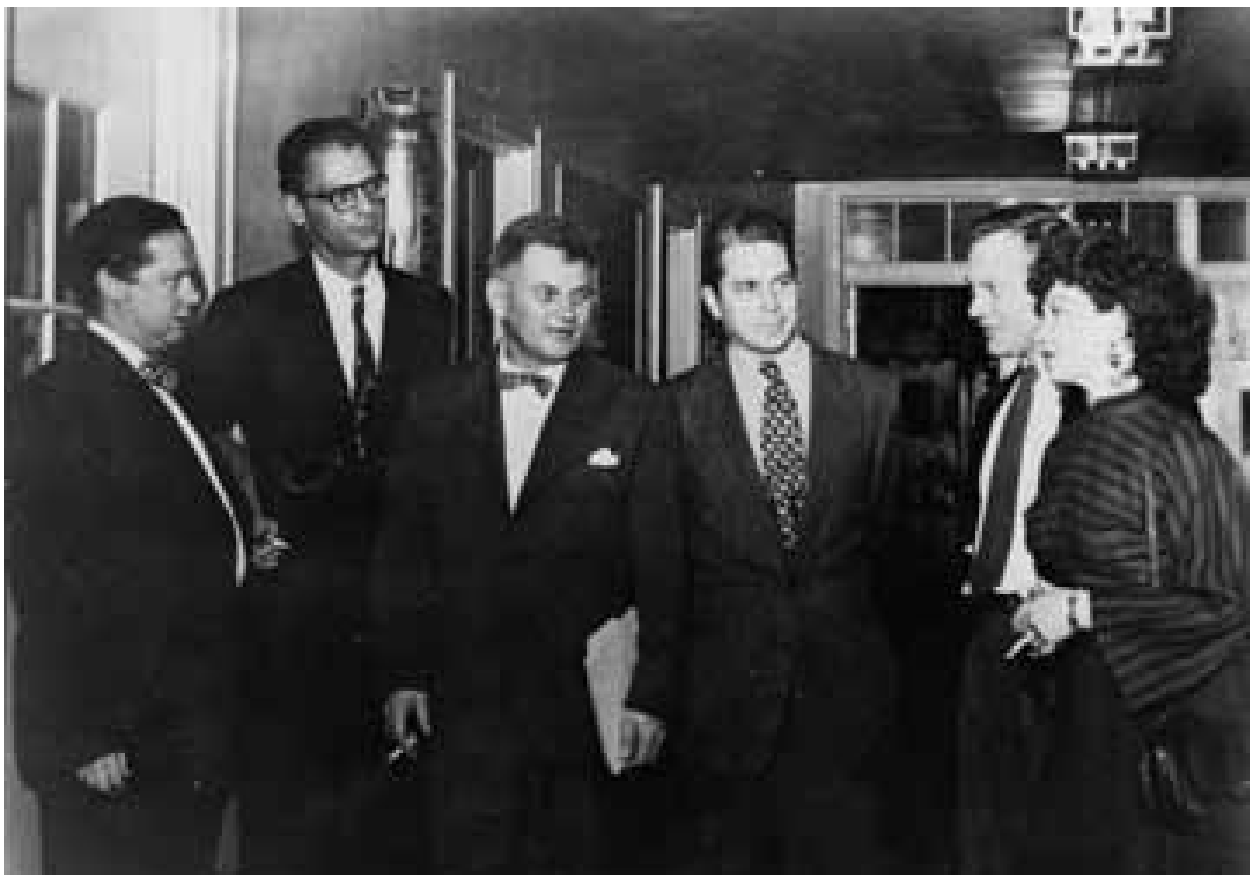

Maya Deren with (left to right) Dylan Thomas, Arthur Miller, Willard Maas, Parker Tyler and Amos Vogel. Cinema 16 symposium, "Poetry and the Film," October 28, 1953. Reproduced with kind permission of the Maya Deren Collection, Howard Gottlieb Archival Research Centre at Boston University.

Maya Deren and her cat. (no date) Reproduced with kind permission of the Maya Deren Collection, Howard Gottlieb Archival Research Centre at Boston University.

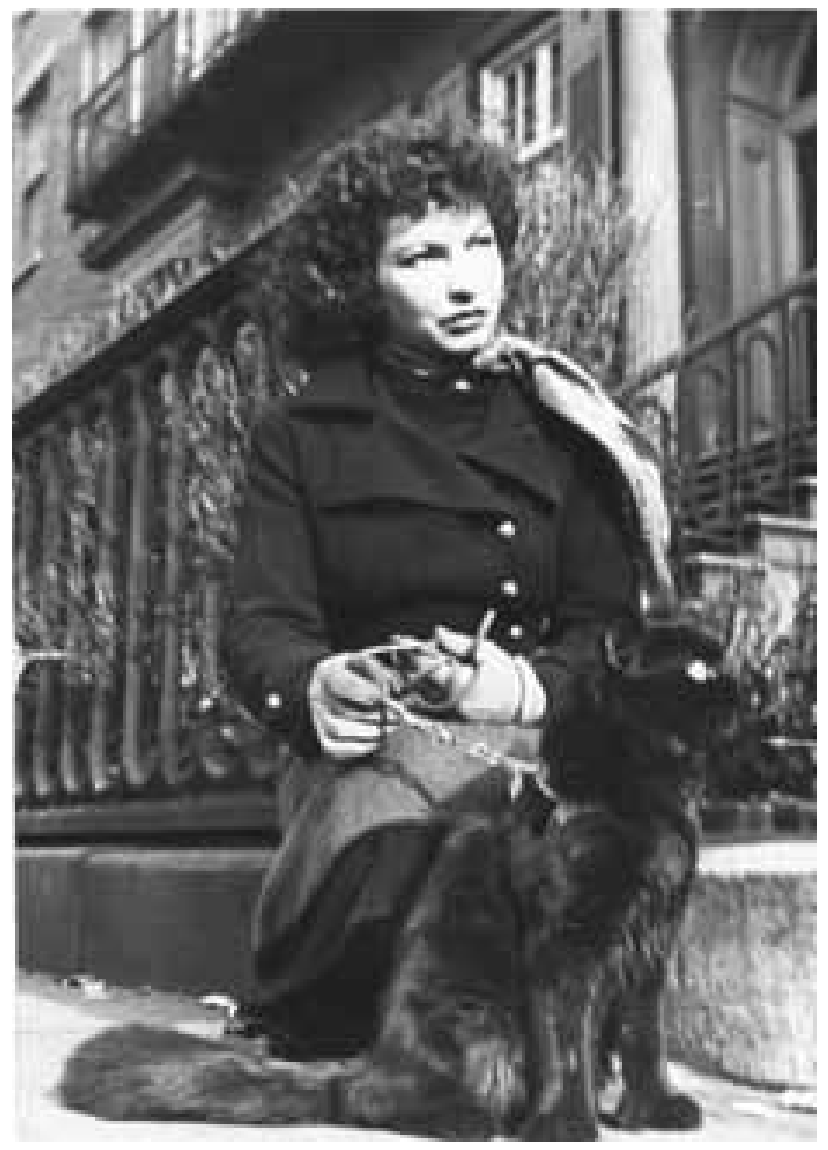

